\title{
Arab-Islamic Reception and Development of Hellenistic Science
}

\author{
Giovanna Lelli \\ University of Ghent, Ghent, Belgium \\ Email: Giovanna.Lelli@UGent.be
}

Received 19 January 2015; accepted 28 February 2015; published 30 March 2015

Copyright (C) 2015 by author and Scientific Research Publishing Inc.

This work is licensed under the Creative Commons Attribution International License (CC BY). http://creativecommons.org/licenses/by/4.0/

(c) (i) Open Access

\section{Abstract}

This article is an overview of the Arab-Islamic reception and development of Hellenistic science. It particularly refers to mathematics, physics and astronomy. It focuses on the following topics: 1) Two interpretative models of this reception in the $19^{\text {th }}, 20^{\text {th }}$, and $21^{\text {st }}$ century scholarship: the "Indo-European model" (which supposes a cultural heterogeneity between Greece and Islam) and the "cosmopolitan Hellenistic model" (which supposes homogeneity between the two). 2) The channels through which Hellenistic science was transmitted to the Islamic world: the philological channel, and the oral channel which implies the pre-existence of a common Greek-Semitic cultural ground that made this transmission possible. 3) Three features of the Arab-Islamic sciences that highlight their essential contribution to the emergence of modern science in $16^{\text {th }}$ and $17^{\text {th }}$ century Europe: 3.1. The "democratising" character of the Arab-Islamic sciences resulting from a larger diffusion of literacy. 3.2. The higher precision of measurements and calculations. 3.3. The experimental approach of Muslim scientists. A positive role in the accomplishment of these advances has been played by the non-metaphysical character of orthodox Islamic monotheism. According to Muslim orthodoxy, there are no Neo-Platonic intermediaries between the almighty God and his creation. The whole universe is submitted to the same physical laws. I argue that today it is important to open an interdisciplinary debate on the Arab-Islamic sciences. It would certainly lead to a better appreciation of their historical contribution. It could also suggest answers to contemporary epistemological impasses deriving from the growing gap between the humanities and the sciences ${ }^{1}$.

\section{Keywords}

Sciences, Islam, Europe, History, Humanities

\footnotetext{
${ }^{1}$ The content of this article was originally a presentation. Lelli, G. (2014). Arab-Islamic Reception of Hellenistic Philosophy and Science. Presentation given at the Doctoral School on "Methods and Interpretation in Classics" organised by the Ghent Institute for Classical Studies (GIKS), University of Ghent, September the $5^{\text {th }} 2014$.
} 


\section{Introduction}

This article is an overview of the Arab-Islamic reception and development of Hellenistic science. I intend the term science in the narrow sense of natural and exact sciences, although in post-Hellenistic cultures philosophy and science were tightly related, according to the epistemological universe well exemplified by Aristotle's classification of the sciences into theoretical, practical and productive (Metaphysics, book 6), as described in Porphyry's Isagoge 2 . I can quote in this respect the Arab historian Ibn Khaldūn (d. 1406) who in his Muqaddima relied upon a well-rooted model of classification of sciences, based on the distinction between the religious traditional sciences and the philosophical sciences. The philosophical (hikmiyya falsafiyya) or "intellectual” ('aqliyya) sciences are: $\operatorname{logic}^{3}$, physics, metaphysics and mathematics.

The intellectual sciences are natural to man, in as much as he is a thinking being. They are not restricted to any particular religious group. They are studied by the people of all religious groups who are all equally qualified to learn them and to do research in them. (...) They are called the sciences of philosophy and wisdom. They comprise four different sciences.

1) The first science is logic (...)

2) Then, philosophers may study the elemental substances perceivable by the senses, namely, the minerals, the plants, and the animals which are created from (the elemental substances), the heavenly bodies, natural motions, and the soul from which the motions originate, and other things. This discipline is called "physics". It is the second of the intellectual sciences.

3) Or they may study metaphysical, spiritual matters. This science is called "metaphysics" (al-'ilm al-ilâhî). It is the third of the intellectual sciences.

4) The fourth science is the study of quantities (measurements). It comprises four different sciences, which are called the "mathematical sciences" $\left(\operatorname{ta}^{\text {‘ }} \mathrm{a} l \mathrm{l} m\right)^{4}$.

In this respect it is significant that Galileo Galilei (d. 1642) still used the term "philosophy" to indicate what later scholarswould call "science":

Philosophy is written in that great book which ever lies before our eyes-I mean the universe-but we cannot understand it if we do not first learn the language and grasp the symbols, in which it is written. This book is written in the mathematical language, and the symbols are triangles, circles and other geometric figures, without whose help it is impossible to comprehend a single word of it; without which one wanders in vain through a dark labyrinth ${ }^{5}$.

It is not only a question of vocabulary. For Galileo, the senses ("il senso") are inseparable from deductive reason ("le ragioni dimostrative necessarie"). Galileo's usage reflects the inseparable association between philosophy and science typical of the pre-modern universal system of knowledge which took centuries to disintegrate. For some aspects it even survived until the early $20^{\text {th }}$ century. It partially survived until the time when the education systems still provided a complete curriculum including both the "sciences" and the "humanities", although epistemologically separated. Koyré (1973) insists on the decisive role of theory more than experience in the scientific revolutions of the $17^{\text {th }}, 19^{\text {th }}$ and $20^{\text {th }}$ century. "Thus the Galilean conception of a correct scientific procedure implies (...) the prevalence of theory over facts” ${ }^{6}$. Koyré's conclusion in this respect is categorical:

The great revolutions of $20^{\text {th }}$ century science, as well as those of the $17^{\text {th }}$ and the $19^{\text {th }}$, although based on the discovery of new facts (or on the failure to verify them), are fundamentally theoretical revolutions. In my view their result was not a better correlation between the data of experience, but the acquisition of a new

\footnotetext{
${ }^{2}$ Nasr (1968): 59-64. Jolivet (1996): 1008-1025.

${ }^{3}$ Logic is actual instrumental, âliyya, of the philosophical sciences.

${ }^{4}$ Ibn Khaldūn (1967): Vol. 2, 436; Ibn Khaldūn (2001): 629-630.

${ }^{5}$ “La filosofia è scritta in questo grandissimo libro che continuamente ci sta aperto innanzi a gli occhi (io dico l'universo, ma non si può intendere se prima non s’impara a intender la lingua, e conoscer i caratteri, ne' quali è scritto. Egli è scritto in lingua matematica, e i caratteri son triangoli, cerchi, ed altre figure geometriche, senza i quali mezzi è impossibile a intenderne umanamente parola; senza questi è un aggirarsi vanamente per un oscuro laberinto" [Galileo (1844): 171].

“"La manière dont Galilée conçoit une méthode scientifique correcte implique (...) une primauté de la théorie sur les faits” [Koyré (1973): 83].
} 
concept of the reality underlying these data ${ }^{7}$.

The Arab-Islamic contribution to the history of science of which I'm going to analyse some of the relevant aspects, can only be understood by taking into full account the universal and integrated system of knowledge in which the Islamic scientists operated.

In this article I will go through the following topics. First I will distinguish between two interpretative models of the Arab-Islamic reception of Hellenistic science in $19^{\text {th }}, 20^{\text {th }}$ and $21^{\text {st }}$ centuries' scholarship: the "IndoEuropean model" (which presumes a cultural heterogeneity between Greece and Islam) and the "cosmopolitan Hellenistic model" (which presumes a cultural homogeneity between the two). Secondly I will draw attention to the channels through which the Hellenistic sciences were transmitted to the Islamic world: the philological channel and the oral channel. The latter implies the pre-existence of a common Greek-Semitic cultural ground that made this transmission possible. Thirdly I will highlight some features of the Arab-Islamic sciences which represent essential advances with respect to Hellenistic science and contributed to the birth of modern science. These features can be summarised by the following three elements: the "democratising" character of the ArabIslamic sciences resulting from a larger circulation of knowledge, the higher precision of measurement and calculations and the experimental approach of Islamic scientists. These features contributed to what the historian and philosopher of Arab science Rashed (2004) has called the emergence of a new rationality, both algebraic and experimental ${ }^{8}$.

A positive role in the accomplishment of these advances has been played by the non-metaphysical character of orthodox Islamic monotheism. According to Muslim orthodoxy there are no Neo-Platonic intermediaries between the almighty God and his creation. The whole universe is subject to the same physical laws. Instead a factor that was at once an obstacle and an advantage was the insufficient formality of the Islamic mathematical language, which remained discursive and philosophical.

In my conclusion I will argue that today it is important to open an interdisciplinary debate on the Arab-Islamic sciences. It would certainly lead to a better appreciation of their historical contribution. It could also suggest answers to contemporary epistemological impasses deriving from the growing gap between the humanities and the sciences.

\section{Two Interpretative Models of the Reception of Greek Philosophy and Science in the Islamic World}

As far as the historical interpretation of the Arab-Islamic reception of Hellenistic science is concerned, I distinguish between two interpretative models in modern historical scholarship: the Indo-European model and the cosmopolitan Hellenistic model. If there is a general consensus on the fact that the Arab-Islamic civilisation played a role in transmitting Greek philosophy and science to late medieval and early modern Europe, opinions are different about the meaning and content of this reception and about the historical contribution of Islamic science. In a schematized manner I propose to distinguish between the two fundamental interpretative models: the "Indo-European model" and the cosmopolitan "Hellenistic model". My analysis partially relies upon Bernal's work on the Afro-Asiatic roots of Classical Greece (Bernal, 1987). These two models are not coherent and explicit theories, but they act as paradigms in contemporary scholarship. They can coexist in a single theory or author, or one can prevail on the other.

The $19^{\text {th }}$ century Indo-European interpretative model of the reception of Greek philosophy and science in pre-modern Islam is well exemplified by the position of the $19^{\text {th }}$ century French Orientalist Ernest Renan. Renan's theories contributed to the shaping of $19^{\text {th }}$ century European ideology which needed to affirm the superiority and originality of European culture in order to legitimize colonial policies, denying all kinship between Greek and Arab/Semitic thought. The difference between Semitic and Indo-European languages provided a "scientific" argument for these theories. It was only after the $2^{\text {nd }}$ world war that the Jews were "rehabilitated"

\footnotetext{
${ }^{7}$ Free English translation is mine. "Les grandes révolutions scientifiques du XXème siècle—autant que celles du XVIIème et du XIXèmebien que fondées naturellement sur la découverte de faits nouveau—ou sur l’impossibilité de les vérifier—sont fondamentalement des révolutions théoriques dont le résultat ne fut pas de mieux relier entre elles les données de l'expérience”, mais d'acquérir une nouvelle conception de la réalité profonde qui sous-tend ces données” [Koyré (1973): 86].

${ }^{8}$ Rashed (1996): vol. 2, 349-375.

${ }^{9}$ Bernal (1987). Bernal distinguishes between the “ancient model” and an “Arian model” in the historical interpretation of the Greek civilization.
} 
and the notion of "Judeo-Christian culture" became a well-established category (Amin, 1999). For Renan Arabic philosophy is nothing but Greek philosophy written with Arabic characters (Renan, 1882). In a book on Semitic linguistics, he exposed his theory on Semites whose "race", he said, has only negative characters: it has no mythology, no epics, no science, no philosophy, no plastic arts, and no civil life... it has no variety in its monotheism (Renan, 1855) ${ }^{10}$. Renan's approach, although in a less categorical manner, affected Western Orientalism until deep into the $20^{\text {th }}$ cent. Contemporary Islamic studies declare having abandoned this model, but it partially re-emerged in the last few years as a result of the unprecedented impact of the media on cultivated classes and scholarship, in our informational society. Today's media tend to explain the history of the Arab-Islamic world in exclusively religious terms, as if religion was the only identitarian feature of the peoples of the region and the only interpretation key for their history. In this respect the notion of religion has become very close to the notion of race.

The second interpretative model of the reception of Greek philosophy and science in medieval Islam, which I called the cosmopolitan "Hellenistic model", appeared in the $20^{\text {th }}$ century. If we read certain Orientalist publications of the years seventies of the last century we can observe the affirmation of a cosmopolitan interpretation of Antiquity, Hellenism and the Middle-Ages, refuting the $19^{\text {th }}$ century prejudice of a cultural specificity of ancient Greece or Christianity with respect to the Arabs and Islam. Orientalist scholars, who especially in past generations had a solid philological background in Greek and Latin philology, were aware that the Arab-Islamic reception of Greek philosophy and science was not only the result of the translation of a large amount of Greek texts into Arabic, but also of a much older interaction between the peoples of the ancient Near East and the Hellenistic Mediterranean. For orientalists like Bausani (1978) or Kunitzsch (1975) it was clear that the Byzantine world, the Islamic world and the Latin world all flourished on common Hellenistic basis. Bernal, with his Black Athena (1987), translated their "empirical" awareness into a systematic theory, relying upon philological and archaeological arguments. Bernal shows that classical Greece had not been an isolated miracle, despite its extraordinary cultural achievements, but it was the continuator of the cultures of ancient Mediterranean (Egypt and Mesopotamia). As far as the pre-Islamic Arabian Peninsula is concerned, it was a peripheral area of Hellenism. Christian, Jewish, Zoroastrian and Manichean elements penetrated pre-Islamic Arabia from Byzantine Syria, Yemen and Iran through oral channels. When the Arab caliph al-Ma'mūn supported a huge translation movement of Greek texts into Arabic in the $9^{\text {th }}$ century, the Greek heritage found in the Muslim culture a familiar cultural environment, ready to assimilate and develop it. The years sixties and seventies of the last century were of course also the years of political and social attempts to build a more egalitarian world. The independence of colonised countries, the emergence of the non-aligned countries after the Bandung conference (1955), and the confrontation between the capitalist and the socialist blocks created a cultural environment generally more favourable than today to openness, pluralism and cosmopolitism. In the field of Arab and Islamic studies among the scholars who explicitly adopted the cosmopolitan Hellenistic model in the recent decades I can quote the economist Amin (1988), the orientalist Arkoun (1991), the epistemologist Abed al-Jabri (1999, 2006), the philosopher de Libéra (1993), and the historian and philosopher of science Rashed (1996, 2004).

The break between the Age of Antiquity and the medieval era is not to be found where conventional Eurocentric history places it, that is, at the end of the Western Roman Empire in the first centuries of the Christian era. I situate this division much earlier, during the time of Alexander the Great, at the moment of the Hellenistic unification of the East (335 B.C.E.). The medieval era, therefore, includes the Hellenistic (including Roman), Byzantine, Islamic (including Ottoman), and Western Christian (feudal) worlds ${ }^{11}$.

In the field of the history of science, Rashed (2004) focuses on the same unity and continuity in the history of the Mediterranean, saying that the birth of modern science in Europe relies upon the emergence of a "new rationality", "algebraic and experimental”, in the Arab world as early as the $9^{\text {th }}$ century.

This new rationality can be called, in brief, algebraic and experimental. It characterizes classical modernity and was established between the $9^{\text {th }}$ and the $12^{\text {th }}$ centuries by scholars scattered between Muslim Spain and

\footnotetext{
${ }^{10}$ Quoted by Bernal (1987).

11،La coupure âge antique/âge médiévale ne se situe pas là où l'histoire conventionnelle eurocentrique la place, c'est à dire à la fin de l'Empire romain d’Occident (...) Nous situons cette coupure plus tôt, à l'époque d'Alexandre le Grand, c'est à dire à l'époque de l'unification hellénistique de l’Orient (...) L’âge médiéval comprend donc la succession (ou la co-extension) des mondes hellénistiques (romain inclus), byzantine, islamique (ottoman inclus) et chrétien occidental (féodal)”, [Amin (1988): 44].
} 
the borders of China, but who all wrote in Arabic. The appropriation of this new rationality by the [Western] scholars began in the $12^{\text {th }}$ century and a new emulation of it took place then in the $16^{\text {th }}$ century and gave rise to subsequent improvements. Therefore in order to understand classical modernity it is essential to break with that periodization established by the historians based on a causal link between the events of the political history, the religious and literary history of the Renaissance and those of the sciences ${ }^{12}$.

Today scholars of Arab and Islamic studies almost unanimously declare that they accept the cultural unity of the Mediterranean. But in the meanwhile the world scene has changed. The acceleration of globalisation does not go together with cosmopolitism. On the contrary, the recent years have been characterised by a generalised withdrawal into narrow religious, linguistic, ethnic and communitarian identities. Of course these developments have an impact on scholarship. This is why in my view the cosmopolitan Hellenistic interpretative model, although formally accepted, remains unachieved, often limited to a declaration of principles or applied to very specific case studies. Was Bernal (1987) to much of an optimistic in foreseeing that the "ancient model" of the Afro-asiatic roots of ancient Greece would prevail in the scholarship at the beginning of the $21^{\text {st }}$ century?

\section{The Channels through Which Hellenistic Science Was Transmitted to the Islamic World}

As far as the channels through which the Hellenistic sciences were transmitted to the Islamic world, I distinguish between the philological channels and the oral channels. The interaction between ancient science and the Arabs did not start with nor was it limited to the translation movement of the "House of Wisdom" (Bayt al-hikma), which was established by the Arab caliph al-Ma'mūn in 830. Al-Ma'mūn's Bayt al-hikma continued a centurieslong cultural tradition. A fundamental role in the process of the textual transmission of Greek philosophy and science to the Arab-Islamic world has been played by the Christian Syriac élite. Syriac was a Middle Aramaic language and the most prestigious religious and culture language of Eastern Christianity between the $2^{\text {nd }}$ and the $8^{\text {th }}$ century A.D. Syriac Christians translated a great amount of Greek philosophical texts into Syriac then into Arabic, or directly into Arabic. They did so for theological purposes, but they became interested also in philosophy and science. The encounter between ancient science and the Arabs did not start with nor was it limited to the various schools of Greek theology, philosophy and science that were established in the Near East before Islam in Harran, Edessa and Qinnesrin (Syria), in Nisibis (upper Iraq) and Jundishapur (Iran) and which continued to function in Islamic times, when they were joined by other study centres. The encounter between linguistically Semitic and Afro-asiatic cultures and areas and Indo-European cultures goes back centuries before. Orientalism has focused almost exclusively on the philological channel of transmission of Greek texts translated into Arabic. Textual evidence is easier to verify than oral transmission, which remains a ground for hypothesis which is difficult to evaluate. Orientalists, as I mentioned before, had a solid background in philology and classical scholarship, a field of studies that played a fundamental role in the construction of what Bernal calls the "Arian model”: an image of ancient Greece cut off from its Egyptian and Mesopotamian roots.

Orientalist scholars like Bausani and Kuntzisch have pointed out that it would be inadequate to rely exclusively upon the philological channel in the reconstruction of the Arab-Islamic reception of Greek thought and science. Bausani (1976) has shown that Encyclopaedia of the Brotherhood of Purity (Rasā'il Ikhwān al-Safầ), an Arabic Ismaili treatise probably composed in the $9^{\text {th }}$ century, mentions the same measures of the stellar parallax as the measures proposed by Hipparchus ( $2^{\text {nd }}$ cent. B.C.) that have been preserved in Hellenistic texts, of which no Arabic translation is known. "The problem is far from being solved (...) but there are scholars like Sezgin who assume the possibility that the Muslims had a much older and larger knowledge of the ancient Greek legacy than previously thought"13. Kunitzsch (1975) has the same opinion about the Arab-Islamic reception of the Greek religion.

\footnotetext{
${ }^{12}$ Free English translation mine. "Cette nouvelle rationalité, qui peut se dire en bref algébrique et expérimentale, et qui caractérise la modernité classique, a été fondée, nous l'avons dit, entre le IXe et le XIIe siècle, par les savants dispersés entre l’Espagne musulmane et les confins de la Chine, mais qui tous écrivaient en arabe. L'appropriation de cette nouvelle rationalité par les savants a commencé au XIIe siècle, et une nouvelle émulation verra le jour à partir du XVIe siècle, donnant lieu à des perfectionnements. Il paraît donc indispensable, pour qui veut comprendre la modernité classique, de rompre avec cette périodisation tracée par les historiens, fondée sur un lien causal entre les événements de l'histoire politique, religieuse et littéraire de la Renaissance, et ceux de la science”, [Rashed (2004), 13].

${ }^{13}$ Bausani (1978): 19-20, who quotes Kunitzsch (1975). Sezgin’s full name is Fuat Sezgin.
} 


\section{The Arab-Islamic Contribution to the Emergence of Modern Science}

\subsection{The Democratizing Character of the Arab Islamic Sciences}

I will now refer to the fact that the Arab-Islamic sciences, and particularly mathematics, physics and astronomy, have been characterised by three features that constitute essential advances with respect to the Hellenistic sciences. As Bausani (1985) points out, these features are: the "democratising" character of the Arab-Islamic sciences resulting from a larger diffusion of literacy, the higher precision of measurements and calculations and the experimental approach of scientists. Rashed (2004) argues that these features have contributed to the emergence of a new rationality, both algebraic and experimental, which entertains a relationship of continuity with the birth of modern science in the $17^{\text {th }}$ century.

It is commonly accepted that modern science flourished in Europe in the $16^{\text {th }}, 17^{\text {th }}$ and $18^{\text {th }}$ centuries with the works of Copernic, Galileo, Kepler and Newton. Historians have observed that the birth of modern science was not only the result of the genius of those great scientists, but also a response to social transformations that eventually led to the industrial revolution.

A materialistic explanation is obvious. The unprecedented economic growth of the $18^{\text {th }}$ century raised the whole world of which Europe became the necessary heart. Material and technical life multiply their demands, their constraints (...) Industrialization has been the decisive element, the engine ${ }^{14}$.

Unlike pre-modern science, modern science cannot be defined any longer in geographical terms. It is true that until today it remains dominated by Western research and investment, but it is a world science of a world system: capitalism. Europe has created world science, said Braudel $(1993)^{15}$ quoting the historian of Chinese science Joseph Needham ${ }^{16}$. Before modern times, science could be defined in geographical terms: there was a Greek science, an Indian science, a Chinese science, an Arab-Islamic science, etc. Relying upon Bausani (1985), I believe that we can summarize the development of Hellenistic science by the Arab-Islamic civilisation and therefore its historical contribution to the birth of modern science with the following three features: the "democratising" character of the Arab-Islamic sciences resulting from a larger circulation of knowledge, the experimental approach of scientists, and the higher precision of their calculations.

Medieval Islam made a decisive step towards the democratisation of knowledge. Thanks to a relatively broader diffusion of writing, Islam made knowledge and science accessible to a larger class than was the case before. Texts and information circulated more widely. The cultivated class remained an "élite" (khāsssa or khawāss ), but larger than before. Rashed points out that a passage of the Arabian Nights puts in the mouth of a Barber of Baghdad the pride of being acquainted with all the sciences, including geometry, arithmetic, astronomy and algebra ${ }^{17}$. Bausani (1985) observes that one is not always aware that great Greek scientists like Archimedes ( $3^{\text {rd }}$ cent. B.C.), Hipparchus $\left(2^{\text {nd }}\right.$ cent. B.C.) or Diophantus ( $3^{\text {rd }}$ cent. A.D.) were isolated individuals surrounded by a society that was more primitive than classical scholarship thought. In this respect the Islamic contribution to world science does not consist only in specific advances in mathematics, physics, astronomy and the other sciences but also in its capacity to summarise and simplify the Hellenistic scientific legacy. Islam made accessible to a larger audience and to posterity a great amount of material coming from the ancient Mediterranean and Greece, through the Hellenistic filter. Texts like the before-mentioned Ras $\bar{a}^{\prime}$ il Ikhwān al-Safă' and the Muqaddima of Ibn Khaldūn ${ }^{18}$ are perfect examples of this capacity of synthesis.

This synthesis is then expressed in a style that I would define a wonderful tool for popularisation purposes (...) I mention this expressive aspect of the Ikhwān's Encyclopaedia, an aspect that may appear purely formal, because it actually reflects a fundamental character of the Arab-Islamic culture. This character is that the Arab-Islamic culture has simplified and organised in a whole easier to digest all the materials coming from the ancient Mediterranean, from Egypt and from the Ancient East on the one hand, and from precedent monotheistic religions, Judaism and Christianity on the other. It has been the last classical culture and

\footnotetext{
${ }^{14}$ Free English translation is mine. "Une explication matérialiste est évidente. L’essor économique sans précèdent du XVIIIe siècle a soulevé le monde entier et l’Europe en est devenue le cœur impérieux. Vie matérielle et techniques multiplient leurs demandes, leurs contraintes (...) L’industrialisation serait ainsi l'élément décisif, le moteur” [Braudel (1993): 495].

${ }^{15}$ Braudel (1993): 487.

${ }^{16}$ Needham (1954-2004).

${ }^{17}$ Rashed (2004): 3.

${ }^{18}$ Especially the $6^{\text {th }}$ part of the Muqaddima: on "The various kinds of sciences".
} 
the first modern one, or rather the intermediary between the two ${ }^{19}$.

\subsection{The Higher Precision of Measurements and Calculations}

Besides the "democratising" character of the Arab-Islamic sciences, another feature that represents an essential advance with respect to Hellenistic science is its precision in measurements and calculations. Koyré (1948) defined the modern world as the world of "precision", as opposed to the ancient "world of approximation". The higher precision of Islamic science is particularly evident in the field of astronomy, a field in which the Arab-Islamic scholars made remarkable advances thanks to their use of trigonometry. Al-Battānī (d. 929), author of Al-Zïj al-Sāabi' (an astronomical handbook with tables in the tradition of Ptolemy's Almagest and Handy Tables $)^{20}$, is an outstanding example of accuracy in astronomical and geographical measurements.

The accuracy of Battān̄̄s observations of equinoxes and solstices, as judged from the one existing report and his determination of the lengths of the seasons, is not much inferior to that of Tycho Brahe 700 years later. This remarkable achievement must have been due to a careful construction and alignment of his large instruments, as well as to a clever method of combining multiple observations of the same type of phenomenon (which was certainly not simple averaging). The value obtained by Battānī for the Ptolemaic solar eccentricity, expressed sexagesimally as 2, 4, 45 parts out of 60, is almost exact. In fact, it is clearly better than the values found by Nicolaus Copernicus, who was troubled by refraction because of his high geographical latitude, and Brahe, who incorporated the much too high Ptolemaic value for the solar parallax in the evaluation of his observations.

Battānī also made accurate measurements of the obliquity of the ecliptic, which he found as $23^{\circ} 35^{\prime}$ (the actual value in the year 880 was $\left.23^{\circ} 35^{\prime} 6 "\right)$, and the geographical latitude of Raqqa (36 $6^{\circ}$, modern value $\left.35^{\circ} 57^{\prime}\right)$. Furthermore, he determined all planetary mean motions anew. He found the parameters of the lunar model to be in agreement with Ptolemy and the eccentricity of Venus the same as derived by the astronomers working under Ma'mūn (see, for example, Yahyā ibn Abī Manșūr). Battān̄̄ also confirmed the discovery of Ma'mūn's astronomers that the solar apogee moves by $1^{\circ}$ in 66 Julian years, and found the precession of the equinoxes to be equal to the motion of the solar apogee. He accurately measured the apparent diameters of the Sun and the Moon and investigated the variation in these diameters, concluding that annular solar eclipses are possible. In the $18^{\text {th }}$ century, Battān̄is observations of eclipses were used by Richard Dunthorne to determine the secular acceleration of the motion of the Moon ${ }^{21}$.

\subsection{The Experimental Character of the Arab-Islamic Sciences}

Further to the "democratising" character of the Arab-Islamic sciences and their higher precision, I will now mention a third element, which is their "experimental" character. There is no agreement between scholars on the meaning of the term "experimental" when referring to the Arab-Islamic sciences. Koyré (1973) criticised the idea of a historical continuity between the Middle Ages and the origin of modern science. For him there is no experimental method before Galileo. Koyré established a clear difference between "experience" and the "experiment". Experience is the result of sensual observation. "The physics of Aristotle is based on the perception of the senses, and for this reason it is resolutely non-mathematical”,22. The experiment, instead, supposes a theory, the elaboration of language to question nature, to select and order the data of observation.

Galileo knows that experience-or if I may use the Latin word experimentum in order to better oppose it to common experience which is simple observation-Galileo knows that the experimentum must be prepared, that the experimentum is a question asked to nature, a question asked in a very special language, in the

\footnotetext{
${ }^{19}$ Free English translation is mine. "Questa sintesi è poi espressa in uno stile che definirei un mirabile strumento di divulgazione (...) Menziono questo aspetto espressivo, che può parer solo formale, della Enciclopedia degli Ikhwân perché esso riflette un carattere fondamentale della cultura arabo-islamica. Quello cioè di essere stata la semplificatrice, la organizzatrice in un tutto unitario di più facile digestione, dell'insieme di materiali provenienti, attraverso il filtro della cultura ellenistica, dall'antico Mediterraneo, dall'Egitto, dall'Antico Oriente da una parte e dalle precedente religioni monoteistiche, Ebraismo e Cristianesimo, dall'altra. E' l'ultima cultura classica e la prima moderna o meglio l'intermediario fra i due mondi”, [Bausani (1978): 21].

${ }^{20} \mathrm{Al}$-Battānī (1899-1907).

${ }^{21}$ Van Dalen (2007): 101-103.

22،“La physique d’Aristote est basée sur la perception sensible, et c’est pour cela qu’elle est résolument anti-mathématique”, [Koyré (1973): 201].
} 
geometric and mathematical language $(\ldots)^{23}$.

Koyré had a limited access to Arab-Islamic scientific sources. Although he spent several years in Cairo, I don't think he had an adequate knowledge of Arabic. In any case he does not quote sources in Arabic. Rashed (2004), Bausani $(1971,1985)$ and other Arabist scholars who adhere to what I called the "cosmopolitan Hellenistic model”, focus on the experimental attitude of the Arab-Islamic scientists. They consider that there is a historical continuity between the Arab-Islamic "Middle Ages" and the birth of modern science and highlight the historical contribution of the Islamic sciences in this respect. However Bausani (1985) does not seem to attribute a theoretical content to the Arab-Islamic experimental attitude. Rashed, instead, argues that the "Arab sciences" are characterised by a new rationality, both algebraic and experimental, which entertains a link of historical continuity with the later emergence of modern science in Europe. He analyses the experimental content of the Optic (Kitāb al-Manāzir) of Ibn al-Haytham (d. 1040 ca. $)^{24}$.

We have also witnessed the emergence of a new concept of proof in physics, and we have seen how we accept from this moment on that the state of existence of a physical object is no longer its "natural" state but simply that of its experimental setup ${ }^{25}$.

Bausani observes that precision and experiment were facilitated by the anti-metaphysical monotheism of orthodox Islam. According to Muslim orthodoxy, well represented by the ash'arite theologian Abū Bakr al-Bāqillānī (d. 1013), there are no Neo-Platonic intermediaries between the almighty God and his creation. The whole universe is submitted to the same physical laws. Against those who identified God with the celestial spheres, al-Bāqillānī wrote:

We know that the stars are temporal (not eternal), they have been created by God and they have the same properties of the other bodies of the universe. They have a beginning, an end, a composition, a state of motion, a state of rest and they change from one state to another. Therefore if we admitted that they were eternal, we should admit that all the other bodies were also eternal ${ }^{26}$.

Ibn Khaldūn, who considered himself an orthodox ash'arite Muslim, introduced the scientific method in the study of history ${ }^{27}$, thanks to his simultaneous materialistic, empirical and rationalistic approach. He said that history relies upon a scientific analysis of facts, and not upon the authority of the transmitters. Therefore the historians should not attribute the Qur'ān implausible statements just because some authoritative sources mention them.

Untruth naturally afflicts historical information. There are various reasons that make this unavoidable. One of them is partisanship for opinions and schools. If the soul is impartial in receiving information, it devotes to that information the share of critical investigation the information deserves, and its truth or untruth thus becomes clear. However, if the soul is infected with partisanship for a particular opinion or sect, it accepts without a moment's hesitation the information that is agreeable to it. Prejudice and partisanship obscure the critical faculty and preclude critical investigation. The result is that falsehoods are accepted and transmitted. Another reason making untruth unavoidable in historical information is reliance upon transmitters ${ }^{28}(\ldots)$ Even more unlikely and more deeply rooted in baseless assumptions is the common interpretation of the following verse of the Surat al-Fajr: Did you not see what your Lord did with 'Ad-Iram, that of the pillars? The commentators consider the word Iram the name of a city which is described as having pillars, that is, columns. They report that 'Ad b. 'Us b. Iram had two sons, Shadid and Shaddid, who ruled after him.

\footnotetext{
${ }^{23}$ Free English translation is mine. “Galilée sait que l'expérience-ou si je peux me permettre d'employer le mot latin d'experimentum pour l’opposer justement à l'expérience commune, à l'expérience qui n’est qu’observation-que l'experimentum se prépare, que l'experimentum est une question posée à la nature, une question posée dans un langage très spécial, dans le langage géométrique et mathématique (...)”, [Koyré (1973): 59].

${ }^{24}$ Ibn al-Haytham (1983).

${ }^{25}$ Free English translation is mine. "Nous avons également assisté à l'émergence de la nouvelle conception de la preuve en physique, et nous avons vu comment on admet désormais que le plan d'existence d'un objet physique n'est plus son plan naturel, mais simplement celui de son montage expérimental”, [Rashed (2004): 13]. See also Rashed (1996): vol. 2, 349-375.

${ }^{26}$ Free English translation is mine.

"العلمنا بحدوث هذه النجوم و أنها جارية مجري سائر أجسام العالم و ذلك أنه قد جاز عليها من الحدو النهايةو التأليف و الحركة و السكون و الانتقال من حال إلى حال ما يجوز (...)

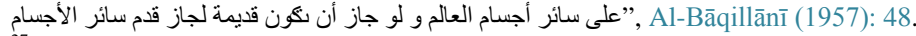

${ }^{27}$ See for example Lacoste (1998).

${ }^{28}$ Ibn Khaldūn (1967): vol. 1, 71-72; Ibn Khaldūn (2001): 46.
} 
Shadid perished. Shaddad became the sole ruler of the realm, and the kings there submitted to his authority. When Shaddad heard a description of Paradise, he said: "I shall build something like it". And he built the city of Iram in the desert of Aden over a period of three hundred years. He himself lived nine hundred years. It is said to have been a large city, with castles of gold and silver and columns of emerald and hyacinth, containing all kinds of trees and freely flowing rivers. When the construction of (the city) was completed, Shaddad went there with the people of his realm. But—when be was the distance of only one day and night away from it, God sent a clamor from heaven, and all of them perished. This is reported by at-Tabari, ath-Tha'alibi, az-Zamakhshari, and other Qur' an commentators (...)

No information about this city has since become available anywhere on earth (...)

All these suggestions proffered by Qur' an commentators were the result of grammatical considerations (...) There is no need for such an implausible interpretation which uses for its starting point silly stories of the sort mentioned, which cannot be imputed to the Qur'an because they are so implausible ${ }^{29}$.

Bausani $(1978,1985)$ likes to quote the Islamic scientist and polymath Al-Bīrūnī (d. 1048) as well as Galileo, remarking the striking similarity in the criticism of both towards those who rely upon the Holy texts for their knowledge of astronomy and science ${ }^{30}$. Indeed al-Bīrūnī in his The chronology of Ancient Nations (Al-Athār al-bāqiya) remarks that Qur'ān's commentators are wrong when they interpret astronomical information in the Qur'ān in a way that contradicts what is evident to our senses ("how could we believe a thing the contrary of which is evident to our senses?”31):

"Day, Night, and the Duration of the Day of Fast"

(...) This is the general definition of the day which we give, the night being included. Now, if we proceed to divide and to distinguish, we have to state that the words "Yaum" (day) in its restricted signification, and "Nahâr" (day), mean the same, viz., the time from the rising of the body of the sun till its setting. On the other hand, night means the time from the setting of the body of the sun till its rising. Thus these two terms are used among all nations by general consent, nobody disputing their meanings, except one Muslim lawyer, who has defined the beginning of the day to be the rise of dawn, and its end to be the setting of the sun, because he presumed that the day and the duration of fasting were identical. For this view of his he argues from the following word of God (Sura ii. 183): "Eat and drink till you can distinguish a whitethread from a black thread at the light of dawn. Thereupon fast the entire day till the night”. Now, he has maintained that these two terms (dawn and night) are the two limits of the day (beginning and end). Between this view, however, and this verse of the Coran there is not the slightest connection whatsoever. For if the beginning of fasting was identical with the beginning of the day, his (God's) definition of something that is quite evident and well known to everybody, in such terms, would be like a pains-taking attempt to explain something void of sense. Likewise he has not defined the end of day and the beginning of night in similar terms, because this is generally known among all mankind. God orders that fasting should commence at the rise of dawn; but the end of fasting he does not describe in a similar way, but simply says that it should end at "night", because everybody knows that this means the time when the globe of the sun disappears. Hence it is evident that God, by the words of the first sentence (i.e. eat and drink till you can distinguish a white thread from a black thread at the light of dawn), does not mean the beginning of day (...)

Now, if people say that God, in this verse (Sura ii. 183), wanted to teach mankind the beginning of the day, it would necessarily follow that before that moment they were ignorant of the beginning of day and night, which is simply absurd.

Now, if people say the legal day is different from the natural day, this is nothing but a difference in words, and the calling something by a name, which, according to the usage of the language, means something else. And, besides, it must be considered that there is not the slightest mention in the verse of the day and of its beginning. We keep, however, aloof from pertinacious disputation on this subject, and we are willing to agree with our opponents as to the expressions if they will agree with us regarding the subject-matter. And

\footnotetext{
${ }^{29}$ Ibn Khaldūn (1967): vol. 1, 25-28; Ibn Khaldūn (2001): 18-20.

${ }^{30}$ Bausani (1985), 656, quotes Galielo’s Letter to Benedetto Castelli (1613): “Crederei che fusse molto prudentemente fatto se non si permettesse ad alcuno impegnare i luoghi della scrittura ed in certo modo obbligargli a dover sostenere per vere queste o quelle conclusion naturali delle quali una volta il senso e le ragioni dimostrative necessarie ci potessero manifestare il contrario", Galilei (1843), 16: "I should think it would be prudent not to allow anyone to oblige scriptural passages to have to maintain the truth of any physical conclusions whose contrary could ever be proved to us by the senses and demonstrative and necessary reasons".

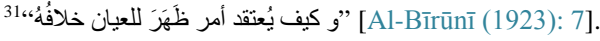


how could we believe a thing the contrary of which is evident to our senses? For evening-twilight in the west corresponds to morning-dawn in the east; both arise from the same cause, and are of the same nature. If, therefore, the rise of morning-dawn were the beginning of the day, the disappearance of evening-twilight would be its end. And actually some Shiites have been compelled to adopt such a doctrine.

My only object in all I have discussed in this place is to refute the opinion of those who think that those things which are necessary for certain philosophical or physical causes prove the contrary of that which is indicated by the Coran, and who try to support their opinion by the doctrine of one of the lawyers ${ }^{32}$.

I think that there are elements that justify a modernist interpretation of Islamic science. Bausani defines Islamic science "proto-modern", associating it withphilosophical rationalistic trends well represented by Averroes (d. 1198). Rashed simply speaks of "modernity". Other scholars, like Hogendijk (2002), do not share this modernist interpretation. Hogendijk criticizes Rashed's views on Ibn al-Haytham's geometry (Completion of the Conics) and more generally Rashed's interpretation of the historical role of Islamic science. For Hogendijk thiskind of interpretations lead to a"naive glorification of medieval Islamic mathematics".

In my view, Ibn al-Haytham was a creative mathematician whose Completion of the Conics, while an interesting historical text, reaches the heights neither of most geometrical works by Archimedes nor of the Conics of Apollonius. This difference of interpretation suggests a cautionary tale. Medieval mathematical texts can often be clarified by an analysis of their contents in terms of more recent mathematics, but what kinds of historical conclusionscan legitimately be drawn from such an analysis? Interpreting Islamic mathematics in terms of $17^{\text {th }}$ and $19^{\text {th }}$ century concepts leaves one open to the danger of attributing concepts to Islamic mathematicians that they did not possess and of describing developments in Islamic mathematics that did not actually happen. Such interpretations may lead to a naive glorification of medieval Islamic mathematics. A methodology that draws from the extensive modern literature on Greek mathematics and that thus places medieval Islamic mathematics in context helps avoid these pitfalls. Moreover, analyzing the achievements of medieval Islamic mathematicians in context allows for an examination of their failures and errors as well as their successes. While the successes are important, the errors and failures reveal the limits of the mathematical capabilities of the medieval Islamic mathematicians, and thereby aid us in reaching a fuller understanding of the rich complexity of the medieval Islamic mathematical tradition ${ }^{33}$.

I think that this question goes beyond the purely empiric philological study of Arab and Islamic sources and the number of "errors" and failures of Islamic mathematicians. It is a historical and a philosophical question. The appreciation of the historical role and value of the Islamic sciences is tightly related to the theoretical interpretation of what is "modern science”. In Koyré's terms, it is a question of theoretical assumptions. In Kuhn's terms ${ }^{34}$, it is a question of paradigms. It is still an open debate.

\section{Conclusion}

The purpose of this article was to provide a critical overview of the Arab-Islamic reception and development of Hellenistic science. I referred to Arab-Islamic mathematics, physics and astronomy, although I also mentioned the Arab historian Ibn Khaldūn for his early scientific and materialistic approach to historiography. I considered a number of topics that highlight the historical contribution of the Arab-Islamic sciences to the emergence of modern science in the $16^{\text {th }}, 17^{\text {th }}$ and $18^{\text {th }}$ centuries. I considered the question of whether the Greek civilization was a "foreigner" to the Arab-Islamic civilization, or whether it belonged to the same cultural background. Then I considered the question of whether the Arab-Islamic reception of Hellenistic science was a simple "transmission" of texts to Medieval and early modern Europe, or whether it was a development of the Hellenistic sciences. I then referred to the different channels of transmission of the Hellenistic sciences to the Arab-Islamic world: a textual channel and an oral channel.

With respect to all these questions, I distinguished between two interpretative models of the history and the philosophy of science (but also of the general history of the Mediterranean) which coexisted in the $19^{\text {th }}$, $20^{\text {th }}$ and $21^{\text {st }}$ century scholarship: the "Indo-European model” and the "cosmopolitan Hellenistic model”. Schematically, the Indo-European model considers that the Arab-Islamic civilization was a foreigner to the Greek one, that its

\footnotetext{
${ }^{32} \mathrm{Al}-\mathrm{B} \bar{r} \mathbf{r} \bar{n} \overline{1}$ (1879): 7-8. Italics is mine. Arabic edition: Al-Bīrūn̄̄ (1923).

${ }^{33}$ Hogendijk 1 (2002): 257.

${ }^{34}$ Kuhn (1962).
} 
historical role was a transmission role, or worse, that this transmission was compromised by deformations and errors. The cosmopolitan Hellenistic model, instead, focuses on the affinity and kinship between Hellenism and Islam, thanks to sharing a millennia long common cultural background in which oral scientific and cultural transmission played a relevant role. According to this model the Medieval Mediterranean, with its Byzantine, Latin and Arab-Islamic components, is conceived as a cultural system that flourished on a common Hellenistic basis. I explained that these two models are not two different schools of thought, but they act as paradigms in contemporary scholarship. They can coexist in a single theory or author, or one can prevail on the other. Although the Hellenistic cosmopolitan model seems to be commonly accepted today, the fragmentation of contemporary scholarship and the identitarian cultural closure of the current stage of globalization are an obstacle to its concrete affirmation.

I then referred to three features of Arab-Islamic science that confirm validity of the cosmopolitan Hellenistic model: its democratizing character, the higher precision of its measurements and calculations, and its experimental approach. Its democratizing character was due to higher diffusion of literacy and to the circulation of a great number of scientific compendia, handbooks, encyclopedia and digests, as well as proper scientific works. As for precision, I referred to the concrete example of al-Battānī's calculations of the obliquity of the solar elliptic (according to the geocentric Ptolemaic system) and the longitudinal motion of the solar apogee which follows the precession of the equinoctials. Then I referred to a more controversial feature, namely the "experimental” approach of Muslim scientists. I also referred to Bausani's remarks on the positive role played by Islamic orthodoxy in this respect. According to Muslim orthodoxy there are no Neo-Platonic intermediaries between the almighty God and his creation. The whole universe has the same properties and it is submitted to the same physical laws. However I pointed out that scholars are divided between those who see in Galileo's experimental method a rupture with the previous history of science (Koyré), and those who see a historical continuity between the Arab-Islamic experimental approach and modern science (Bausani, Rashed). I argued that these different points of views essentially do not depend on the degree of philological correctness of their appreciation of the Arab-Islamic sciences. They depend on different theoretical, ideological and paradigmatic assumptions.

In my concluding remarks I would like to highlight the importance of the study of the Arab-Islamic sciences by a large range of scholars, but not only the few who have a solid background at once in the sciences, the history and philosophy of science and Arabic philology ${ }^{35}$. A wider interdisciplinary debate on the Arab-Islamic sciences could lead to a better appreciation of their historical role on the long path toward modern science. Among the scholars of humanities, mathematics and physics are taboo. If questioned on these disciplines they would answer: "I know nothing about mathematics”, cutting the conversation short. I'm sure that the history of science would benefit from their interest in "mathematics".

Besides a better historical appreciation of the historical role of Islamic science, I can see another advantage in enlarging the scholarly debate on this subject. The very interest of the study of history is always the fact that the comprehension of the past allows us to better understand the present, to find answers to its problems and new paths toward the future. In this respect I think that the Arab-Islamic sciences are a living heritage and can play a positive role. The achievements of Islamic science in the fields of mathematics, physics, astronomy and medicine would not have been possible without the universal system of knowledge to which it belonged. That system included the philosophical sciences (mathematics, physics and metaphysics) and the religious sciences, together with the "instrumental" sciences (logic and linguistics). The most brilliant Muslim scientists, like al-Bīrūnī, were able to recognize the autonomy of scientific investigation from theological considerations and Koranic exegesis. The same autonomy has been recognized by Ibn Khaldūn in the field of historiography. These advances were made despite but also thanks to the universal cultural system within which the Muslim scholars operated.

I also mentioned that one of the obstacles of Arab-Islamic mathematics was the unsufficient formality of its language. It was at once a disadvantage and an advantage. Muslim mathematicians continued to use the discursive language of philosophy. Discursive exposition made mathematics and sciences intelligible to a larger number of people than it is the case for today's mathematics. What is needed today is the use of a simple philosophical language to make sciences and humanities communicate with each other, without prejudice to the use of highly formal languages or various technical languages among specialists.

Today scientists operate in a fragmented cultural universe, characterized by a growing rupture between the "humanities" and the "hard" sciences. Natural and exact sciences have lost much of their theoretical and specu-

\footnotetext{
${ }^{35}$ See Hogendijk 2 (2002): “a call for popularizing ancient mathematics”, $189 \mathrm{f}$.
} 
lative dimension. Hyper-specialization, fragmentation, dependence on technological applications and market demand, the monopoly on scientific research and a growing gap between the humanities and the sciences are obstacles to qualitative and progressive advances in science. The humanities, in their turn, have lost the benefit of a stimulating and healthy dialogue with natural and exact sciences. As a result the social sciences are tempted to use pseudo-scientific arguments in order to legitimise their theses. Quantitative data are used in economics as if numbers were themselves a proof of validity. Or else, postmodern philosophy and its heirs simply renounce interpreting reality, in the name of ending the great narratives ("les grandes narrations") and their "metaphysical” assumptions. I argue that pre-modern scientific traditions like the Islamic one, thanks to the features I have exposed in this article, can play a role in suggesting answers to contemporary impasses.

I would like to conclude with a quotation not from a scientific work but from the Masnavi of the Persian mystic poet Jalāl al-Dīn Rūmī (d. 1273). It is the well-known story of an elephant in the dark. It tells the story of people who brought an elephant in a dark house. Many visitors came to see it. But because of the darkness they could only feel it with their hands. For one the elephant was like a water-spout, for another a fan, for another a pillar or a throne. None could feel the elephant for what it was. Although the conclusion drawn by Rūmī is a mystical contempt for sensual knowledge and the sensual world, what is fascinating in this story with respect of my arguments is the idea that fragmented knowledge is misleading.

"The disagreement as to the description and shape of the elephant"

The elephant was in a dark house:

some Hindus had brought it for exhibition.

In order to see it, many people were going,

every one, into that darkness.

As seeing it with the eye was impossible,

was feeling it in the dark with the palm of his hand.

The hand of one fell on its trunk:

he said, "This creature is like a water-pipe".

The hand of another touched its ear:

to him it appeared to be like a fan.

Since another handled its leg, he said,

"I found the elephant's shape to be like a pillar".

Another laid his hand on its back:

he said, "Truly, this elephant was like a throne".

Similarly, whenever anyone heard,

he understood the part that he had touched.

On account of the place of view, their statements differed:

one man entitled it "dál", another "alif

If there had been a candle in each one's hand,

the difference would have gone out of their words.

The eye of sense-perception is only like the palm of the hand:

the palm has not power to reach the whole of him.

The eye of the Sea is one thing and the foam another:

leave the foam and look with the eye of the Sea.

Day and night the movement of foam-flecks from the Sea:

you behold the foam, but not the Sea. Marvelous!

We are dashing against each other, like boats:

our eyes are darkened, though we are in the clear water.

$\mathrm{O}$ you that have gone to sleep in the body's boat, you have seen the water, look on the Water of the water.

(...)

Keep drowning me every instant, I am pleased:

Your ordinance is my soul, $\mathrm{I}$ bear it as my soul.

I do not look at any one, and even if I do look at, he is a pretext, and You are the object of my regard. 
I am in love with Your making in thanksgiving and patience;

how should I be in love, like the infidel, with that which You have made?”

He that loves God's making is glorious;

he that loves what He has made is an unbeliever ${ }^{36}$.

\section{References}

Abed al-Jabri, M. (1999). Arab-Islamic Philosophy. A Contemporary Critique. Austin: The Centre for Middle Eastern Studies at the University of Austin.

Abed al-Jabri, M. (2006). Naḥnu wa al-turāth. Beirut: Centre for Arab Unity Studies.

Al-Bāqillānī (1957). Kitāb al-tamhīd. P. R. J. McCarthy (Ed.). Beirut: 1957.

Al-Battānī (1899-1907). Al-Battān̄i sive Albatenii Opus astronomicum (al-Zīj al-Șābi'). C. A. Nallino (Ed.), 3 Vols. Milano: Ulrich Hoepli.

Al-Bīrūnī (1879). The Chronology of Ancient Nations. E. Sachau (Transl.). London: W. H. Allen \& Co.

Al-Bīrūn̄i (1923). Chronologie Orientalistiker Völker. E. Sachau (Ed.). Leipzig. http://www.albiruni.nl/

Amin, S. (1999). Judaism, Christianity and Islam: An Introductory Approach to their Real or Supposed Specificities by a Non-Theologian. In A. Mueller, A. Tausch, \& P. Zulehner (Eds.), Global Capitalism, Liberation Theology, and the Social Sciences: An Analysis of the Contradictions of Modernity at the Turn of the Millennium. New York: Nova Science Publishers.

Amin, S. (1988). L'Eurocentrisme. Critique d'une idéologie. Paris: Anthropos economica.

Arkoun, M. (1991). La pensée arabe. Paris : PUF.

Bausani, A. (1985). Il contributo scientifico. In F. Gabrieli (Ed.), Gli Arabi in Italia (pp. 629-660). Milano: Garzanti Scheiwiller.

Bernal, M. (1987). Black Athena. The Afro-Asiatic Roots of Classical Civilization. Vol.1: The Fabrication of Ancient Greece, 1785-1985. London: Free Association Books.

Braudel, F. (1993). Grammaire des civilisations. Paris: Flammarion.

De Libéra. A. (1993). La philosophiemédiévale. Paris: PUF

Galilei, G. (1843). Le Opere complete di Galileo Galilei. Vol. II: Lettere intorno al sistema copernicano. Firenze: Società Editrice Fiorentina.

Galilei, G. (1844). Le Opere complete di Galileo Galilei. Vol. IV: Opere astronomiche. Firenze: Società Editrice Fiorentina.

Hogendijk, J. 1 (2002). Two Editions of Ibn al-Haytham’s Completion of the Conics. Historia Mathematica, 29, $247-265$. http://dx.doi.org/10.1006/hmat.2002.2352

Hogendijk, J. 2 (2002). The Burning Mirrors of Diocles: Reflections on the Methodology and Purpose of the History of Pre-Modern Science. Early Science and Medicine, 7, 181-197. http://dx.doi.org/10.1163/157338202X00108

Ibn al-Haytham (1983). Kitāb al-Manāzir (Optics): Vol. 1-3. Kuwait: Sabra.

Ibn Khaldūn (1967). The Muqaddimah: An Introduction to History. 3 Volumes, Princeton: Princeton University Press.

Ibn Khaldūn (2001). Muqaddima Ibn Khaldūn. Beirut: Dār Al-Fikr. http://ia700408.us.archive.org/0/items/waqtkhldon/tkhldon1.pdf

Jolivet, J. (1996). Classification of Science. In R. Rashed (Ed.), Encyclopedia of the History of Arabic Science (Vol. 3, pp. 1008 f). London and New York: Routledge.

Koyré, A. (1948). Du monde de l'à peu près à l'univers de la précision. In A. Koyré (Ed.), Etudes d'histoire de la pensée philosophique (pp. 341-362). Paris: Gallimard.

Koyré, A. (1973). Etudes d'histoire de la pensée scientifique. Paris: Gallimard.

Kuhn, T. (1962). The Structure of Scientific Revolutions. Chicago, IL: the University of Chicago Press.

Kunitzsch, P. (1975). Uber das Frühstaduium der arabischen Aneignung antiken Gutes. Saeculum, 26, 3. http://dx.doi.org/10.7788/saeculum.1975.26.3.268

Lacoste, Y. (1998). Ibn Khaldūn. Naissance de l'histoire, passé du tiers monde. Paris: La Découverte.

Nasr, S. H. (1968). Science and Civilisation in Islam. Cambridge, MA: Harvard University Press.

Needham, J. (1954-2004). Science and Civilization in China. Cambridge: Cambridge University Press.

${ }^{36}$ Rūmī (1925-1940) (Book 3, verses 1259-1361), 79-85; Rūmī (1368/1990): Vol. 2 (Daftar 3, verses 1259-1361), $72-77$. 
Rashed, R. (2004). Recherche sur la tradition scientifique arabe. In Actes de la Rencontre syro-libanaise de recherche sur la tradition scientifique arabe (pp. 313-333). Beyrouth: Publication de l’Université Libanaise.

Rashed, R. (Ed.) (1996). Encyclopedia of the History of Arabic Science. 3 Volumes, London and New York: Routledge.

Renan, E. (1855). Historire générale et système comparé des langues sémitiques. Paris: Imprimérie Impériale.

Renan, E. (1882). Averroès et l’Averroïsme. C. Lévy (Ed.). Paris.

Rūmī, J. (1368/1990 ca.). Mathnavi-e manavi. 3 Volumes. Teheran: Enteshârât-e Mawlâ.

Rūmī, J. (1925-1940). Masnavi. London: Luzac and Co. https://ia600601.us.archive.org/27/items/Masnavi1Faen/masnavi\%203\%20faen.pdf

Van Dalen, B. (2007). Battānī: Abū Abd Allāh Muḥammad ibn Jābir ibn Sinān al-Battān̄̄ al-Ḥarrān̄̄ al-Ṣābi. In T. Hockey et al. (Eds.), The Biographical Encyclopedia of Astronomers (pp. 101-103). New York: Springer. 